\title{
Technowomen: Women's Autonomy and Its Impact on Environmental Quality
}

\author{
Saima Mujeed ${ }^{1}$, Shuangyan Li ${ }^{1, *}$, Musarrat Jabeen ${ }^{2}$, Abdelmohsen A. Nassani ${ }^{3}$, Sameh E. Askar ${ }^{4} \oplus$, \\ Khalid Zaman ${ }^{5}$, Muhammad Moinuddin Qazi Abro ${ }^{3}$, Sriyanto ${ }^{6} \mathbb{D}$ and Hanifah Jambari ${ }^{7}$
}

1 The School of Economics and Finance, Xi'an Jiaotong University, Xi'an 710049, China; majeed@stu.xjtu.edu.cn

2 International Relations, Faculty Contemporary Studies, National Defense University, Islamabad 44000, Pakistan; jabeen@ndu.edu.pk

3 Department of Management, College of Business Administration, King Saud University, P.O. Box 71115, Riyadh 11587, Saudi Arabia; Nassani@ksu.edu.sa (A.A.N.); mqazi@ksu.edu.sa (M.M.Q.A.)

4 Department of Statistics and Operations Research, College of Science, King Saud University, P.O. Box 11451, Riyadh 11587, Saudi Arabia; saskar@ksu.edu.sa

5 Department of Economics, University of Haripur, Khyber Pakhtunkhwa, Haripur 22620, Pakistan; khalid_zaman786@yahoo.com

6 Social Studies Department, Universitas Muhammadiyah Purwokerto, Purwokerto, Central Java 53182, Indonesia; sriyanto1907@gmail.com

7 Faculty of Social Sciences and Humanities, Universiti Teknologi Malaysia (UTM), Skudai, Johor 81310, Malaysia; hanifah-j@utm.my

* Correspondence: shuangyanli@mail.xjtu.edu.cn

Citation: Mujeed, S.; Li, S.; Jabeen,

M.; Nassani, A.A.; Askar, S.E.; Zaman, K.; Abro, M.M.Q.; Sriyanto; Jambari, H. Technowomen: Women's Autonomy and Its Impact on Environmental Quality. Sustainability 2021, 13, 1611. https://doi.org/ $10.3390 /$ su13041611

Academic Editor: Lucia Corsini

Received: 5 December 2020

Accepted: 29 January 2021

Published: 3 February 2021

Publisher's Note: MDPI stays neutral with regard to jurisdictional claims in published maps and institutional affiliations.

Copyright: (C) 2021 by the authors Licensee MDPI, Basel, Switzerland. This article is an open access article distributed under the terms and conditions of the Creative Commons Attribution (CC BY) license (https:// creativecommons.org/licenses/by/ $4.0 /)$.

\begin{abstract}
The role of women in economic development and the global environment is vital for progressing them towards the United Nations sustainable development goal (SDG-5) that emphasized the need to empower women in every walk of life. The study examines women's autonomy in the sustainable development agenda under China's open innovation system from 1975 to 2019. The study employed an autoregressive distributed lag (ARDL) model, vector autoregressive (VAR) Granger causality, and innovation accounting matrix to estimate parameters. The existing data are summarized and collated in the context of China to explain as a correlational study. The results show that women's autonomy moderated with technology spills over to decrease greenhouse gas (GHG) emissions and substantiate the hump-shaped relationship between them. The increased spending on research and development $(R \& D)$ activities, patent publications, and renewable energy consumption empowers women to be equipped with the latest sustainable technologies to improve environmental quality. The pollution haven hypothesis verifies a given country, where trade liberalization policies tend to increase polluting industries to set up their plants that engaged in dirty production that exacerbate GHG emissions. The causality estimates confirmed that technological innovations and renewable energy consumption leads to women's autonomy. In contrast, females' share in the labor force participation rate leads to an increase in renewable energy consumption. Thus, it is evident that there is a positive role of women in the country's sustainable development.
\end{abstract}

Keywords: technowomen; women's autonomy; GHG emissions; R\&D expenditures; patents applications; renewable energy consumption; China

\section{Introduction}

Gender equality is one of the vital aspects of the United Nations sustainable development goals (SDG-5) that provoked the need to end all forms of gender discrimination in socio-economic and business spheres. Family violence, trafficking, forced marriage, and other exploitation types make a woman more vulnerable in many parts of the civilized world. The United Nations stressed the importance of ensuring universal access to education, health, and reproductive rights of the women that enable them to shared 
household and family responsibilities and make their roles in the economic system. Information and communications technologies (ICTs) help spread the network of technological grids across countries while it quickly allows women to get empowered through enabling technology [1].

In compliance with the United Nations SDG-5, many countries worldwide make their policies to protect women's rights and empower them through different techno reforms. China is no exception and is safeguarding women's rights and interests and including them in the national integrated economic agenda to empower women in socio-economic life [2]. The enforceable laws and regulations to empower women are essential in reaching the United Nations SDGs [3]. The country makes its favorable policies for autonomy for women in political, academic, and business environments [4]. Many female workers are highly ranked as scientists, teachers, and political leaders and have won some national honorary titles. The country significantly progresses in women's health and education index to get quality medical attention and net enrolment rates in compulsory education [5]. The latest data report for World Bank [6] shows that women's business and law index scores are 75.6, while Chinese women's share in the labor force participation rate is about $60.45 \%$. The need to become closer towards 100 percent in achieving female autonomy and a fair labor market share would equip women with technical and knowledge spillovers along with devising strong legislation to empower women to be equally treated as men and to work for the country's development. Figure 1 shows the female labor force participation rate and their autonomy scores for reference.

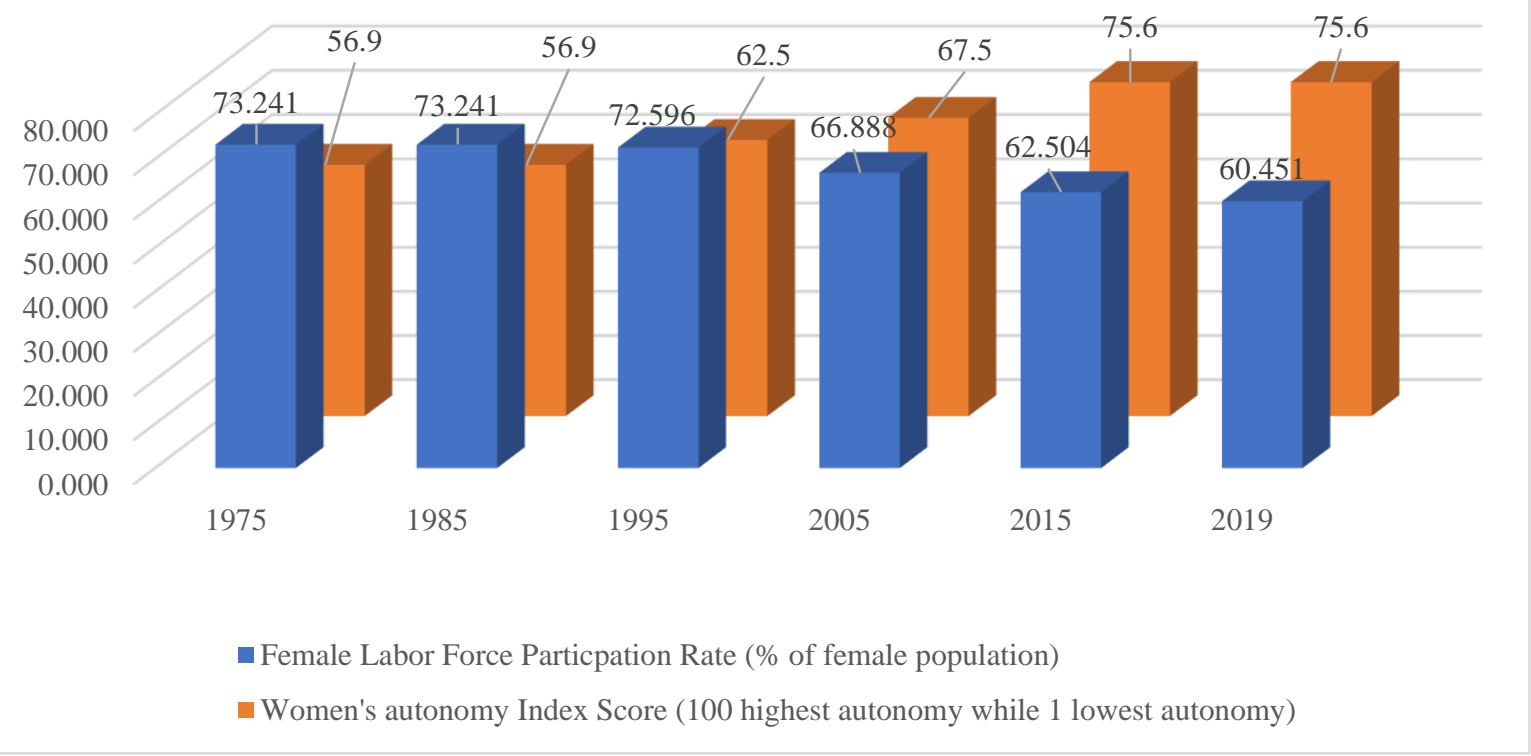

Figure 1. Data trend of women's autonomy in China (1975-2019). Source: World Bank (2020).

The data trend shows the sudden decline in the Chinese female's participation in the labor force from $73.241 \%$ in 1975 to $60.451 \%$ in 2019; while on the other side, women's autonomy index score substantially increases from 56.9 index value in 1975 to 75.6 index value. One of the possible reasons is that women generally have a low autonomy in the country's political affairs that can be viewed in the separate sub-indices of women's autonomy index score that negatively affects them in their productivity, which turned down their participation rate. Figure 2 shows the average growth rate of Chinese technological, economic, and environmental factors during 1975-2019 for reference. 


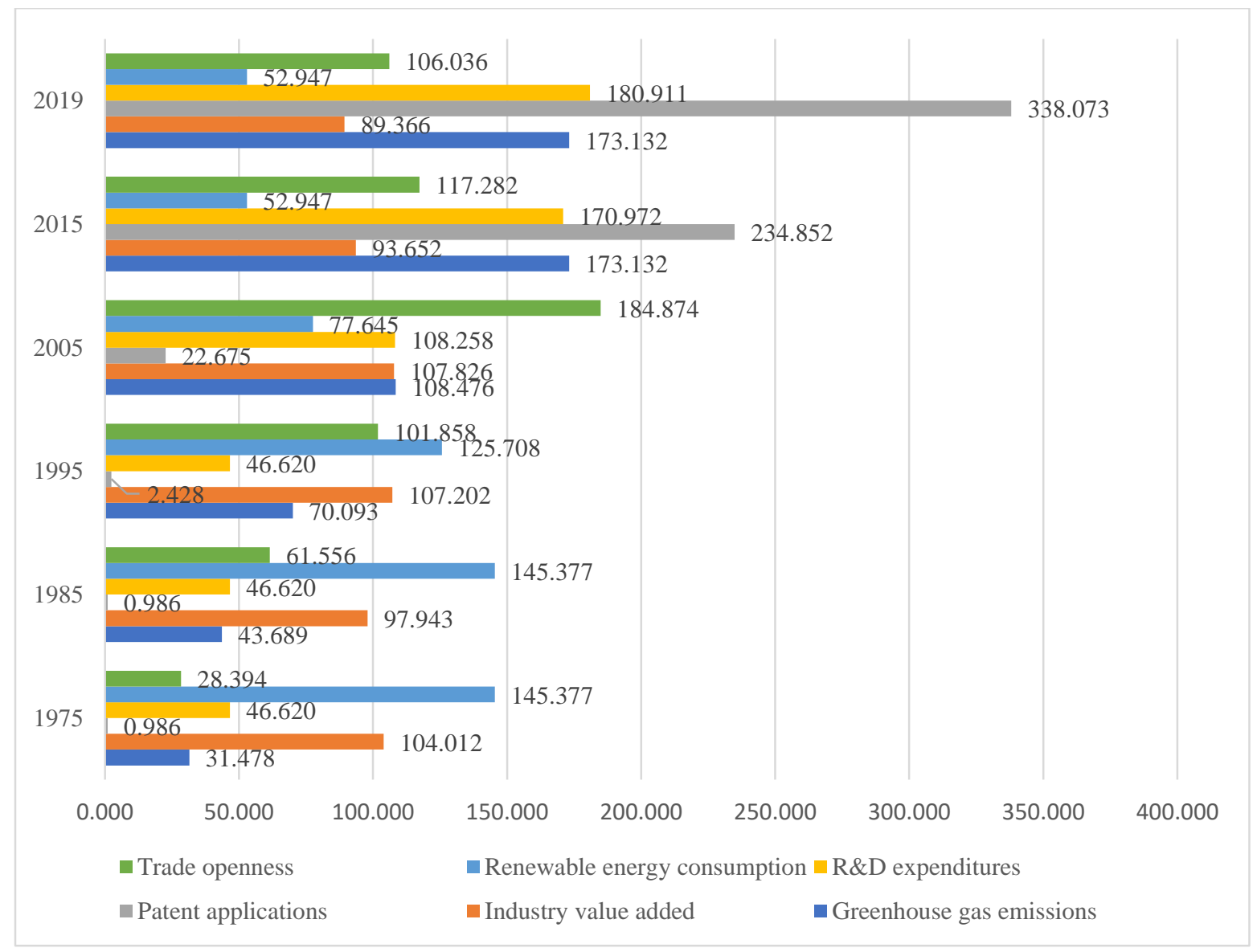

Figure 2. Average percentage growth of technological, economic, and environmental factors in China (1975-2019). Source: World Bank (2020) and author's estimation.

\subsection{Research Question(s)}

After analyzing the data trend of the stated factors, the study moves towards the real problem of the economy related to women's autonomy and their productive role to improve air quality indicators in a country. Thus, the following research questions evaluate techno women's role in the country's sustainable development. Firstly, do technological innovations empower women on the right track to progress in the green growth agenda? This question is essential in various economic dimensions, as technological innovations are mainly considered the main factor in the deteriorating environment through excess energy consumption $[7,8]$. At the same time, women are friendly and have a natural ability to make an environment green and clean. Thus, the amalgamation of both the factors in achieving sustainable green outcomes would likely give some exciting findings that would help policymakers assess the techno women-centric green development approach. Secondly, to what extent women's decisions to use green energy programs help them to achieve the country's sustainable development? This question shows the urgent need to shift non-renewable fuels to renewable fuels that may be possible to give women political autonomy in the country's development programs to minimize the actual cost of carbon emissions. Finally, does stringent environmental regulations helps to vanish polluting industries from national spheres by engaging women in economic affairs? This question showed the importance of reducing technologically associated carbon emissions in trading goods that are the policymakers' growing concerns. Thus, the investment in women is confined to reduced carbon emissions by developing an attitude towards the use of green products, while its political wisdom allows restricting dirty polluting industries from stringent environmental regulations. 


\subsection{Research Objectives}

Based on the stated research contributions and research questions, the study makes the following research objectives to evaluate in the spheres of the Chinese economy.

i. To examine women's autonomy in improving environmental quality through technological innovation factors in a country.

ii. To substantiate the hump-shaped relationship between techno women factors and GHG emissions.

iii. To investigate the role of renewable energy consumption and trade openness in mitigating GHG emissions in the premises of engagement of women role in economic development.

iv. To evaluate the cause-effect relationship and inter-temporal causation between the candidate variables over a time horizon.

The study used a time-series co-integration technique, i.e., autoregressive distributed lag (ARDL) Bounds testing approach, VAR Granger causality, and variance decomposition analysis (VDA) innovation matrix, to achieve the stated objectives the study.

The paper's structure is as follows: after the introduction presented in Section 1; a literature review is shown in Section 2; data and methodology are shown in Section 3; results are in Section 4; Section 5 discussed the results, while the final section concludes the study.

\section{Literature Review}

The earlier literature mainly focused on three different perspectives of female empowerment. Firstly, a sizeable body of literature is available on women's role in economic development [9-17]. These studies confirmed that women significantly played their economic role through accessing ICTs, microfinancing, tourism development, reproductive healthcare decisions, and business entrepreneurship activities. Secondly, the more significant number of earlier literature focuses on women's role in improving the global environment [18-23]. These studies argued that women's role in improving the global environment is merely possible when they fully acquired political autonomy, technology skills, reproductive healthcare treatments, organic agriculture production, energy value chain, financial literacy, and environmental awareness. Thus, these crucial factors help translate women's autonomy in improving the green economy globally. Finally, previous studies evaluated the United Nations SDG-5 with different socio-economic factors [24-28]. These studies showed that gender equality is vital to achieving food security, sustainable outcomes, economic growth, political decisions, and poverty reduction. Table 1 shows different factors through which gender equality could achieve globally. 
Table 1. Main factors affecting global female empowerment and gender equality.

\begin{tabular}{|c|c|c|c|c|c|}
\hline Authors & Country & Women Autonomy Factors & Programs/Factors & Results & Comparison with the Current Study \\
\hline Rehman et al. [29] & Pakistan & Microfinancing & $\begin{array}{l}\text { Akhuwat microfinancing } \\
\text { programs to alleviate rural } \\
\text { women poverty }\end{array}$ & $\begin{array}{l}\text { Akhuwat program is an interest-free } \\
\text { program that improves rural women's } \\
\text { social status to alleviate them from } \\
\text { poverty and sustain their livelihoods to } \\
\text { care household matters. }\end{array}$ & $\begin{array}{l}\text { The current study used some technological factors } \\
\text { that augment women's autonomy, which helps } \\
\text { minimize negative environmental externalities, } \\
\text { while the cited study remains focused on poverty } \\
\text { alleviation through microfinancing. }\end{array}$ \\
\hline Yaya et al. [30] & $\begin{array}{l}32 \text { Sub-Saharan } \\
\text { African countries }\end{array}$ & $\begin{array}{c}\text { Reproductive } \\
\text { healthcare decisions }\end{array}$ & Contraceptive use & $\begin{array}{l}\text { Women played a decisive role in } \\
\text { controlling and commanding } \\
\text { reproductive healthcare decisions by } \\
\text { using contraceptives in family } \\
\text { planning matters. }\end{array}$ & $\begin{array}{l}\text { The cited study confines to assess women's } \\
\text { healthcare status. In contrast, the current study } \\
\text { used R\&D expenditures, trade openness, } \\
\text { renewable energy demand, and women's } \\
\text { autonomy factor vital for achieving } \\
\text { healthcare sustainability. }\end{array}$ \\
\hline Bassani et al. [14] & $24 \mathrm{EU}$ countries & $\begin{array}{l}\text { International tourism } \\
\text { development and access } \\
\text { to finance }\end{array}$ & $\begin{array}{l}\text { Gender parity in net enrollments } \\
\text { in educational institutions, labor } \\
\text { market, and wage matters }\end{array}$ & $\begin{array}{l}\text { Access to finance, enabling women to } \\
\text { sustain their livelihoods and improve } \\
\text { their participation in the labor market by } \\
\text { promoting international tourism. }\end{array}$ & $\begin{array}{l}\text { The cited study uses financial factors along with } \\
\text { education and labor market factors that empower } \\
\text { women. In comparison, it is powerless to add } \\
\text { technological factors incorporated in the current } \\
\text { study to get more robust inferences. }\end{array}$ \\
\hline $\begin{array}{l}\text { Yasmin and } \\
\text { Grundmann [31] }\end{array}$ & Pakistan & $\begin{array}{l}\text { Energy transitions from } \\
\text { non-renewable to renewable fuels }\end{array}$ & $\begin{array}{l}\text { The decision-making process to } \\
\text { use green cooking technologies } \\
\text { for safe and healthy outcomes. }\end{array}$ & $\begin{array}{l}\text { Biogas is an optimized solution that could } \\
\text { minimize women's healthcare concerns } \\
\text { and enable them to make green products. }\end{array}$ & $\begin{array}{l}\text { The cited study emphasized the need to use } \\
\text { biogas in cooking stoves to prevent health } \\
\text { hazards, while it remains limited not to include } \\
\text { R\&D expenditures and technological factors, } \\
\text { which is vital to reduce environmental hazards } \\
\text { added in this study for concrete results. }\end{array}$ \\
\hline Oyawole et al. [32] & Nigeria & $\begin{array}{l}\text { Women's autonomy in smart } \\
\text { agricultural practices }\end{array}$ & $\begin{array}{l}\text { Climate-resilient women } \\
\text { smart strategies }\end{array}$ & $\begin{array}{l}\text { Investment in women in technical aspects } \\
\text { to understand climate mitigation policies } \\
\text { helps them use smart technologies to } \\
\text { combat specific climate issues. }\end{array}$ & $\begin{array}{l}\text { The cited study remains limited to exploring } \\
\text { women's autonomy in smart agricultural } \\
\text { practices, while the current study used few other } \\
\text { vital factors, including R\&D spending on female } \\
\text { labor participation and trade openness that helps } \\
\text { achieve environmental sustainability agenda. }\end{array}$ \\
\hline May [33] & Africa & $\begin{array}{l}\text { Women's environmental } \\
\text { autonomy to progress in } \\
\text { sustainable outcomes }\end{array}$ & $\begin{array}{l}\text { Weather vulnerability affects } \\
\text { women's autonomy in } \\
\text { sustainable healthcare decisions. }\end{array}$ & $\begin{array}{l}\text { Extreme weather effects are } \\
\text { gender-specific, and women's health is } \\
\text { mainly exposed that need sustainable } \\
\text { healthcare outcomes to reduce adverse } \\
\text { weather shocks. }\end{array}$ & $\begin{array}{l}\text { The current study used GHG emissions as an } \\
\text { important factor of environmental degradation } \\
\text { coupled with different women's autonomy } \\
\text { factors, leading to more sustainable healthcare } \\
\text { outcomes than the cited study. }\end{array}$ \\
\hline Goel and Gupta [34] & India & $\begin{array}{l}\text { Women's empowerment through } \\
\text { ICTs usage }\end{array}$ & $\begin{array}{l}\text { The use of smartphones } \\
\text { empowers women in the } \\
\text { economic sphere. }\end{array}$ & $\begin{array}{l}\text { The role of technological development } \\
\text { not only empowers women in performing } \\
\text { their tasks in household and business } \\
\text { entities. Simultaneously, it led to improve } \\
\text { technical abilities to get knowledge from } \\
\text { the globalized world through smart } \\
\text { internet penetration. }\end{array}$ & $\begin{array}{l}\text { The cited study used smartphones as a technical } \\
\text { factor of women's autonomy while powerless to } \\
\text { include more productive technological factors, } \\
\text { including R\&D expenditures and patent } \\
\text { applications, which added to fill this gap. }\end{array}$ \\
\hline
\end{tabular}


Table 1. Cont

Authors Country

Women Autonomy Factors Programs/Factors

Results

Comparison between women's political empowerment and women's socio-economic empowerment for child healthcare decisions child political autonomy an child healthcare decisions

Women's autonomy in loca government reforms

Women's competency framework in the decision-making process

Women entrepreneurship by using their expertise through social media
Women business autonomy

China
[37]

Zhou and Son [38]
China
Women environmentally friendly behavior
Climate change mitigation strategies are gender-sensitive
The socio-economic women's empowerment in child healthcare issues are reasonably significant and help reduce compared to women's political freedom.

Women's equity in local government reforms enables them to get tertiary ducation and equal job opportunities to utilize their public projects expertise.

Social media is not limited to disseminate information and word-of-mouth for entrepreneurial activities, while thi medium use to empower women through developing their business by e-marketing campaigns.

Gendered differences are mainly eviden in climate-resilient policies, as both have significant differences in opinions that can be counter to it with mutual integration of their views for environmental protection.

\section{Comparison with the Current Study}

The cited study remains focused on women's decision to support their family's health

disregarding to evaluate adverse environmental

hazards, which is the leading cause of achieving healthcare sustainability; thus, the current study included socio-economic and environmental factors to resolve this issue.

The cited study evaluated women's autonomy in education and labor market outcomes, while the current study included technological factors and R\&D expenditures to empower women in the decision making process.

The current study used absorptive capability and innovative capacity factors that empower women conventional social media that limited women's entrepreneurial activities.

The current study supported women's environmentally friendly behavior through technological advancement, while the cited study assessed gender differences of pro-environmental behavior short of incorporating some key variables. 
The cause-effect relationship between women's autonomy and environmental quality is also evident in the earlier studies; for instance, Saleem et al. [39] confirmed the oneway causal links between carbon emissions and maternal risks of death from a panel of 21 Asian and African countries. Salahodjaev and Jarilkapova [40] found that a more significant proportion of parliamentarian women have an environmental attitude to conserve nature through increasing forestation. DiRienzo and Das [41] concluded that women's political autonomy improves environmental quality through pro-environmental behavior. Hillman [42] supported the notion of women's political autonomy to mitigate GHG emissions, as the more significant number of women's participation in parliaments supported the climate change legislation, either due to their pro-environmental behavior and due to modernization effect. However, in both situations, women are considered more environmentally friendly compared to men. Lv and Deng [43] considered a positive role of women participating in the civil society matters to improve the natural environment and reduce healthcare concerns that are a matter of chance for parliament to support environmental conservation.

\section{Contribution of the Study}

Based on the current literature review, the study extended the knowledge base by utilizing female empowerment and gender equality modeling agenda and contributed to the earlier literature through four main domains. Firstly, the study included two different types of innovation factors, including R\&D expenditures and total patent publications that have a moderating impact on women's autonomy that can translate them into sustainable outcomes to reduce GHG emissions. The earlier literature limited analyzing mediating technological effects of women's factors to minimize environmental concerns [44-46]. Secondly, the moderation turning point is calculated to understand the required threshold values of female autonomy index score and females' share in labor force participation to enable women to contribute to the country's sustainable development. Thirdly, the green energy agenda is considered in technological factors and women's empowerment to mitigate GHG emissions. The earlier literature is less likely to fill this gap and remains inside to get few inferences from women's autonomy and energy efficiency without moderating technological factors with women's empowerment across countries $[47,48]$. Finally, the trade openness factor is included in the green growth agenda to evaluate the pollution haven hypothesis in Technowomen-centric development, while earlier studies confined it with some other economic factors [49-51].

\section{Data Source and Methodology}

The study used the following variables for estimation. Environmental quality measures by total greenhouse gas emissions (denoted by GHG) in kiloton of carbon equivalent. The two factors measure women's autonomy: first, the index score of women business and law (indicated by WA) with a range of lowest autonomy value of 1 to highest autonomy value of 100; and second, female's participation in the labor force (denoted by FLFPR) in \% of the female population. Technological factors are measured by two factors, i.e., the total counts of residents' patent applications (represented by PAP) and research and development expenditures (denoted by RDE) as \% of GDP. Green energy is measured by renewable energy consumption (marked by REC) as a \% of total end-use energy consumption, and the growth factor is measured by trade openness (denoted by TOP) as \% of GDP. The study used three moderation factors to evaluate environmental quality in China by using the time series data from 1975 to 2019, i.e., (i) patent applications and female's participation in the labor force, (ii) women's autonomy and R\&D expenditures, and (iii) women's autonomy and renewable energy consumption. These moderations would be helpful to assess techno women's green development approach in economic business. The data are collected from the World Bank [6] for estimation. The preceding and succeeding values are used to fill the missing series of the variables where required. 
The economy of China consumes massive energy to gear economic activities. The country spends about $2 \%$ of its GDP share on R\&D activities, while the total count of residents' patent applications substantially grows in the last two decades. The country further concentrates on renewable energy production and its consumption that reached, on average, one-quarter of its GDP. The trade liberalization policies support many technological investments in a country that enable their labor force to participate substantially in economic activities. Women's autonomy in business and law score is more than 60/100 index value, which further reflected in the increasing share of females in the labor force that surpassed around $70 \%$ of females in the total female population in the labor force participation rate, which is increasing over time. Besides all these positive developments, the country strives hard to maintain GHG emissions to improve its air quality. The technology embodied emissions, trade liberalization policies, fossil fuel combustion, and low women's political autonomy are the key factors that exacerbate global carbon emissions. Table 2 shows these crucial facts of the stated variables for ready reference.

Table 2. Descriptive Statistics.

\begin{tabular}{cccccccc}
\hline Methods & GHG & WA & FLFPR & PAP & RDE & REC & TOP \\
\hline Mean & $6,422,027$ & 63.953 & 69.434 & $225,311.9$ & 1.043 & 25.693 & 33.889 \\
\hline Maximum & $12,454,711$ & 75.600 & 73.241 & $1,393,815$ & 2.185 & 34.083 & 64.478 \\
\hline Minimum & $2,264,423$ & 56.900 & 60.451 & 3494 & 0.563 & 11.695 & 8.384 \\
\hline Std. Dev. & $3,728,523$ & 7.095 & 4.506 & $409,436.7$ & 0.603 & 9.245 & 15.570 \\
\hline Skewness & 0.651 & 0.586 & -0.692 & 1.890 & 0.796 & -0.535 & 0.127 \\
\hline Kurtosis & 1.829 & 1.825 & 1.837 & 5.190 & 2.027 & 1.499 & 2.236 \\
\hline
\end{tabular}

Source: World Bank [6]. Note: GHG shows GHG emissions, WA shows women's autonomy, FLFPR shows female labor force participation rate, PAP shows patents application, RDE shows R\&D expenditures, REC shows renewable energy consumption, and TOP shows trade openness.

\subsection{Theoretical Framework}

The labor and capital augmented technologies may increase the country's economic growth; however, it exacerbates air pollution. Thus, it is crucial to equip the labor force, especially women, as women are considered environmentally friendly by its instinct that reflect their natural autonomy, with sustainable technologies to minimize the cost of carbon emissions. Ecofeminist use in this study was moderated with technological spillovers to equip the female labor force with sustainable production technologies to decrease GHG emissions. The earlier literature is available on two different literature streams; the first stream of the earlier literature is highly provoking the positive role of women in economic development $[10,52-54]$. The widespread discrimination and vulnerability are broadly viewed in most developed and developing countries [55-57]. Besides that, women still strive hard to make a space in corporate and economical business and work with equal zeal as their male counterparts [58-61]. Women are mostly viewed in the second stream of literature as more environmentally friendly and sensitive about the environment than the male counterpart. This concept is primarily considered "ecofeminism", which is viewed in different corporate-level activities and green business development practices [62-65]. This study included technological factors in women's autonomy that enable women to become more creative and technical skills, which help them in increasing their share in the labor force participation rate. The study used the word "Technowomen" for the empowered women who used the latest technology and skills to contribute to the sustainable development agenda. Based on the stated literature, the study used the following model that extended it with different technological factors and women's autonomy through interaction term that helps to assess the synergetic impact of the moderation factors on the country's environmental quality, i.e.,: 


$$
\begin{aligned}
& G H G=\Pi_{0}+\Pi_{1} W A+\Pi_{2} F L F P R+\Pi_{3} P A P+\Pi_{4}(F L F P R \times P A P)+\Pi_{5} R D E+\Pi_{6}(W A \times R D E) \\
& +\Pi_{7}(R E C)+\Pi_{8}(W A \times R E C)+\Pi_{9} T O P+\varepsilon \\
& \therefore \frac{\partial G H G}{\partial W A}>0, \frac{\partial G H G}{\partial F L F P R}>0, \frac{\partial G H G}{\partial P A P}>0, \frac{\partial G H G}{\partial F L F P R \times P A P}<0, \frac{\partial G H G}{\partial R D E}>0, \frac{\partial G H G}{\partial W A \times R D E}<0, \frac{\partial G H G}{\partial R E C}<0, \\
& \frac{\partial G H G}{\partial W A \times R E C}<0, \frac{\partial G H G}{\partial T O P}>0
\end{aligned}
$$

where GHG shows GHG emissions, WA shows women's autonomy, FLFPR shows female labor force participation rate, PAP shows patents application, $R D E$ shows R\&D expenditures, REC shows renewable energy consumption, TOP shows trade openness, and $\varepsilon$ shows error term.

Equation (1) shows different technological factors that enable women to participate in the labor force and contribute to sustainable development by using their strategic wisdom and environmentally friendly behavior. It assumes that there will be a hump-shaped relationship between women's autonomy and GHG emissions through the moderation effect of R\&D expenditures and renewable energy consumption that would help reduce GHG emissions. Another moderation effect of the patent application on women's autonomy enables them to contribute to economic activity through technical skills and knowledge transfer, leading to improving environmental quality. Trade openness is expected to increase GHG emissions to verify the pollution haven hypothesis in a country.

The following research hypotheses have given expected relationships between the stated variables as described in Equation (1).

Hypotheses 1 (H1). Technology factors likely to empower women to equip them with technical skills that help them contribute to sustainable development.

Hypotheses 2 (H2). There will be a positive impact of women's autonomy on the environmental quality level in moderation of renewable energy consumption in a country.

Hypotheses 3 (H3). Easiness in trade policies will likely increase pollution through polluting industries to verify the pollution haven hypothesis.

\subsection{Econometric Framework}

These three hypotheses of the study would be empirically tested through time series econometric techniques presented here in Figure 1.

Figure 1 shows the sequential flow of methodology that is used in this study to estimates parameters of interest and discussed here for reference.

\subsubsection{Step-I: Unit Root Test}

In the very beginning, the study evaluated an individual variables series through the breakpoint unit root test by the Augmented Dickey-Fuller method. This test is essential from different perspectives; firstly, this method allows us to assess of the separate order of integration of the candidate variables. The various possibilities we would likely get during estimation, i.e., the candidate variables with the same order of integration or either a first or zero-degree order of integration. The former order confirms the series will become I(1), while the later order will establish the I(0) series. Secondly, this test would assess the mixture of $\mathrm{I}(1)$ and $\mathrm{I}(0)$ variables that remain crucial for using the optimal statistical techniques to produce fair and unbiased coefficient estimates. Thirdly, this test identifies structural shocks during the given period and states break dates in the variables' series. Finally, this test would require a sizeable number of observations of the candidate variables to move forward for the co-integration process.

\subsubsection{Step-II: ARDL Co-Integration Process}

After analyzing the unit root test estimates, a wide variety of co-integration tests are available to estimate parameters, including bivariate co-integration, i.e., Engle-Granger 
co-integration and multivariate co-integration, i.e., Johansen co-integration and ARDL cointegration tests. The Engle-Granger co-integration is based on two variables that exhibit the problem of omitted variables. In contrast, multivariate co-integration tests remain faced with a mixture of $\mathrm{I}(1)$ and $\mathrm{I}(0)$ variables. The Johansen co-integration test would give an optimal result when the variables are I(1) in nature and have adequate time series data. In contrast, the the ARDL co-integration test gives fair results when either of the variables are mixed in order of integration, and it does not require a more significant number of observations of the studied variables. Based on the advantages of ARDL co-integration as proposed by Pesaran et al. [66], the study computes Wald F statistics to assess whether the variables exhibit a co-integration process or not. For this purpose, the Narayan critical values would use that provided the set of critical values both for lower bound I(0) and upper bound I(1). The significant Wald F statistics confirmed that the given series possesses long-run co-integration as it falls in the upper bound I(1) values. The different set of models would assess Wald F statistics, ARDL lag length, and their diagnostic test estimates to find the best suitable model for estimation.

\subsubsection{Step-III: ARDL Bounds Testing Approach}

After confirmation of the co-integration process between the stated variables, the study moves to estimate short- and long-run elasticities to assess the direction and magnitude of the variables. The different lag lengths would be used based on SIC criteria to evaluate the coefficient estimates. The error correction term (ECT) could further be computed during the estimation of coefficients. The following equation would be simultaneously estimated in a schematic fashion of ARDL bounds testing.

$$
\begin{aligned}
& \Delta G H G=\Pi_{0}+\Pi_{1} \sum_{i=1}^{p} \Delta(G H G)_{t-i}+\Pi_{2} \sum_{i=1}^{q} \Delta(W A)_{t-i}+\Pi_{3} \sum_{i=1}^{r} \Delta(F L F P R)_{t-i}+\Pi_{4} \sum_{i=1}^{s} \Delta(P A P)_{t-i} \\
& +\Pi_{5} \sum_{i=1}^{t} \Delta(F L F P R \times P A P)_{t-i}+\Pi_{6} \sum_{i=1}^{u} \Delta(R D E)_{t-i}+\Pi_{7} \sum_{i=1}^{v} \Delta(W A \times R D E)_{t-i}+\Pi_{8} \sum_{i=1}^{w} \Delta(R E C)_{t-i} \\
& +\Pi_{9} \sum_{i=1}^{x} \Delta(W A \times R E C)_{t-i}+\Pi_{10} \sum_{i=1}^{y} \Delta(T O P)_{t-i}+\Phi_{1}(G H G)_{t-i}+\Phi_{2}(W A)_{t-i}+\Phi_{3}(F L F P R)_{t-i} \\
& +\Phi_{4}(P A P)_{t-i}+\Phi_{5}(F L F P R \times P A P)_{t-i}+\Phi_{6}(R D E)_{t-i}+\Phi_{7}(W A \times R D E)_{t-i}+\Phi_{8}(R E C)_{t-i} \\
& +\Phi_{9}(W A \times R E C)_{t-i}+\Phi_{10}(W A \times R E C)_{t-i}+\Phi_{1} 1(T O P) t-i+\varepsilon_{i t}
\end{aligned}
$$

where $\Delta$ shows the first difference operator and $p$ to $y$ shows the optimal lag length. The Wald F statistics are used to verify the following hypothesis in terms of its long-run cointegration existence that substantiates the Narayan critical values:

Hypotheses 4 (H4). $\Pi_{1}=\Pi_{2}=\Pi_{3}=\Pi_{4}=\Pi_{5}=\Pi_{6}=\Pi_{7}=\Pi_{8}=\Pi_{9}=\Pi_{10}=0$

Hypotheses 5 (H5). $\Pi_{1} \neq \Pi_{2} \neq \Pi_{3} \neq \Pi_{4} \neq \Pi_{5} \neq \Pi_{6} \neq \Pi_{7} \neq \Pi_{8} \neq \Pi_{9} \neq \Pi_{10} \neq 0$

The lower and upper bound critical values would be used to verify the co-integration process based on the stated hypotheses. The ECT is computed simultaneously during the estimated Equation (2).

$$
\begin{aligned}
& \Delta G H G=\Pi_{0}+\Pi_{1} \sum_{i=1}^{p} \Delta(G H G)_{t-i}+\Pi_{2} \sum_{i=1}^{q} \Delta(W A)_{t-i}+\Pi_{3} \sum_{i=1}^{r} \Delta(F L F P R)_{t-i}+\Pi_{4} \sum_{i=1}^{s} \Delta(P A P)_{t-i} \\
& +\Pi_{5} \sum_{i=1}^{t} \Delta(F L F P R \times P A P)_{t-i}+\Pi_{6} \sum_{i=1}^{u} \Delta(R D E)_{t-i}+\Pi_{7} \sum_{i=1}^{v} \Delta(W A \times R D E)_{t-i}+\Pi_{8} \sum_{i=1}^{w} \Delta(R E C)_{t-i} \\
& +\Pi_{9} \sum_{i=1}^{x} \Delta(W A \times R E C)_{t-i}+\Pi_{10} \sum_{i=1}^{y} \Delta(T O P)_{t-i}+E C T_{t-i}+\Phi_{1}(G H G)_{t-i}+\Phi_{2}(W A)_{t-i}+\Phi_{3}(F L F P R)_{t-i} \\
& +\Phi_{4}(P A P)_{t-i}+\Phi_{5}(F L F P R \times P A P)_{t-i}+\Phi_{6}(R D E)_{t-i}+\Phi_{7}(W A \times R D E)_{t-i}+\Phi 8(R E C)_{t-i} \\
& +\Phi_{9}(W A \times R E C)_{t-i}+\Phi_{10}(W A \times R E C) t-i+\Phi_{11}(T O P)_{t-i}+\varepsilon_{i t}
\end{aligned}
$$

where ECT shows an error correction term. 
The ECT helps determine the speed of adjustment of the candidate variables in the short-run that was expected to show a convergence of the model towards the equilibrium, which gives an insight into the long-term connection between the stated variables.

\subsubsection{Step-IV: VAR Granger Causality Test}

Subsequently, the VAR Granger causality test performed on the set of variables to substantiate the following set of hypotheses:

Hypotheses 6 (H6). The bidirectional (feedback) causality is expected between the candidate variables.

Hypotheses 7 (H7). The unidirectional (one-way) causality is assumed to running from one variable to other variables and vice versa.

Hypotheses 8 (H8). No causality is assumed to find between the stated variables, although highly correlated.

This test was performed by chi-square distribution on a different set of models and assessed any one of the above stated hypothetical conditions in a given time.

\subsubsection{Step-V: Variance Decomposition Analysis (VDA)}

The VDA test is used here for ex-ante analysis and substituted here for simulation purposes. The test statistics perform over a time horizon that gives forecasting insights about the variables. The test suggests the more significant variance error shocks for exogenous variables on endogenous factors over time. This method provides valuable insights for the policymakers to observe forecast variance error shocks transmitted to the coming years.

There are several limitations of this methodological approach; first, if the variables scattered in terms of their order of integration, i.e., the mixture of $\mathrm{I}(1)$ and $\mathrm{I}(0)$ variables, the ARDL-bounds testing approach is the optimized solution to use it, as conventional co-integration is powerless to give correct estimates in this regard. Second, the data are not required to be as excessive as conventional co-integration requirs a greater number of observations to give significant results. Third, the method used different lag operators to get short- and long-run parameter estimates confined in a few regression apparatuses. Finally, the VAR approach can be better suited to analyze cause-effect relationships and inter-temporal relationships that give the policymakers wisdom to devise effective economic policies.

\section{Results}

Table 3 shows the correlation estimates and found that women's autonomy, trade openness, and open innovation factors (patent applications and R\&D expenditures) substantially increases GHG emissions with a correlation coefficient $\mathrm{r}=0.975 p<0.000, \mathrm{r}=0.826$ $p<0.000, \mathrm{r}=0.977 p<0.000$, and $\mathrm{r}=0.702 p<0.000$ respectively. In contrast, an increasing share of females' share in labor force participation rate and renewable energy consumption decreases GHG emissions with correlation coefficient values of $\mathrm{r}=-0.982 p<0.000$ and $\mathrm{r}=-0.983 p<0.000$, respectively. Further, it is evident from the correlation results that women's autonomy increases by open innovation factors, i.e., there is a positive correlation of patent applications $(\mathrm{r}=0.815 p<0.000)$ and $R \& D$ expenditures $(r=0.958 p<0.000)$ with women's autonomy. Females are more environmentally friendly and greatly caring for their corporate and household environment by using green products $[67,68]$. Hence it is shown that there is a positive correlation between females' share in labor force participation and renewable energy consumption with a correlation estimate of $\mathrm{r}=0.984 p<0.000$. Patent applications increase by an increase in R\&D expenditures and trade openness, whereas R\&D expenditures increase by trade openness. Thus, the correlation estimates confined the directions and magnitude between the candidate variables for further non-linear regression estimators. 
Table 3. Correlation Matrix.

\begin{tabular}{|c|c|c|c|c|c|c|c|}
\hline \multicolumn{2}{|c|}{ Correlation } & \multirow[b]{2}{*}{ WA } & \multirow[b]{2}{*}{ FLFPR } & \multirow[b]{2}{*}{ PAP } & \multirow[b]{2}{*}{ RDE } & \multirow[b]{2}{*}{ REC } & \multirow[b]{2}{*}{ TOP } \\
\hline Prob. & GHG & & & & & & \\
\hline GHG & 1 & & & & & & \\
\hline WA & $\begin{array}{l}0.975 \\
0.000\end{array}$ & 1 & & & & & \\
\hline FLFPR & $\begin{array}{c}-0.982 \\
0.000\end{array}$ & $\begin{array}{c}-0.967 \\
0.000\end{array}$ & 1 & & & & \\
\hline PAP & $\begin{array}{l}0.826 \\
0.000\end{array}$ & $\begin{array}{l}0.815 \\
0.000\end{array}$ & $\begin{array}{c}-0.850 \\
0.000\end{array}$ & 1 & & & \\
\hline RDE & $\begin{array}{l}0.977 \\
0.000\end{array}$ & $\begin{array}{l}0.958 \\
0.000\end{array}$ & $\begin{array}{c}-0.994 \\
0.000\end{array}$ & $\begin{array}{l}0.877 \\
0.000\end{array}$ & 1 & & \\
\hline REC & $\begin{array}{c}-0.983 \\
0.000\end{array}$ & $\begin{array}{c}-0.968 \\
0.000\end{array}$ & $\begin{array}{l}0.984 \\
0.000\end{array}$ & $\begin{array}{c}-0.763 \\
0.000\end{array}$ & $\begin{array}{c}-0.969 \\
0.000\end{array}$ & 1 & \\
\hline TOP & $\begin{array}{l}0.702 \\
0.000\end{array}$ & $\begin{array}{l}0.726 \\
0.000\end{array}$ & $\begin{array}{c}-0.676 \\
0.000\end{array}$ & $\begin{array}{l}0.280 \\
0.061\end{array}$ & $\begin{array}{l}0.623 \\
0.000\end{array}$ & $\begin{array}{c}-0.757 \\
0.000\end{array}$ & 1 \\
\hline
\end{tabular}

Note: GHG shows GHG emissions, WA shows women's autonomy, FLFPR shows female labor force participation rate, PAP shows patents application, RDE shows R\&D expenditures, REC shows renewable energy consumption, and TOP shows trade openness.

Before going for conventional unit root test estimates, the study means equality and variance equality tests are between the given variables' series (see Table 4). The results found that the means and variance of the populations are equal to a hypothesized value of zero, indicating no difference in the given population series. However, more than two samples of the tests are an omnibus that cannot discriminate which groups differ from each other; the study used for the conventional co-integration process started from the unit rot test to make it useful for multiple comparisons to get these inferences.

Table 4. Tests for equality of means and variance between variables.

\begin{tabular}{cccccc}
\hline Methods & Tests & Degree of Freedom & Value & Probability \\
\hline \multirow{2}{*}{ Test for Equality of Means Between Series } & Anova F-test & $6 ; 308$ & 130.528 & 0.000 \\
\cline { 2 - 6 } & Welch F-test & $6 ; 118.494$ & 2296.476 & 0.000 \\
\hline \multirow{2}{*}{ Test for Equality of Variances Between Series } & Bartlett & 6 & 5511.085 & 0.000 \\
\cline { 2 - 6 } & Levene & $6 ; 308$ & 151.143 & 0.000 \\
\cline { 2 - 6 } & Brown-Forsythe & $6 ; 308$ & 55.221 & 0.000 \\
\hline
\end{tabular}

Table 5 shows the estimates of the break unit root test and confirmed that GHG emissions, women's autonomy, females' share in participation in the labor force, and renewable energy consumption are level stationary either at a constant level or constant with the trend. Thus, it becomes the I(0) series. In contrast, the remaining variables, i.e., open innovation and trade openness series, are differenced stationary; thus, it becomes the I(1) series. The combination of I(1) and I(0) variables in the empirical model makes it convenient to utilize in the ARDL co-integration process to give reliable estimates. 
Table 5. Augmented Dickey-Fuller unit root with break test estimates.

\begin{tabular}{|c|c|c|c|c|}
\hline \multirow{2}{*}{ Variables. } & \multicolumn{2}{|c|}{ Level } & \multicolumn{2}{|c|}{ First Difference } \\
\hline & Constant & Constant with Trend & Constant & Constant with Trend \\
\hline \multirow{3}{*}{ GHG } & -4.327 & -4.466 & -3.067 & -4.221 \\
\hline & [2002] & [2002] & [2011] & [2011] \\
\hline & $(0.069)$ & $(0.142)$ & $(0.646)$ & $(0.246)$ \\
\hline \multirow{3}{*}{ WA } & -3.117 & -5.407 & -7.891 & -7.878 \\
\hline & [2003] & [2005] & [2012] & [2012] \\
\hline & $(0.616)$ & $(<0.01)$ & $(<0.01)$ & $(<0.01)$ \\
\hline \multirow{3}{*}{ FLFPR } & -2.676 & -4.802 & -2.196 & -6.952 \\
\hline & [2000] & [2000] & [1995] & [2000] \\
\hline & $(0.839)$ & $(0.058)$ & $(0.963)$ & $(<0.01)$ \\
\hline \multirow{3}{*}{ PAP } & -3.619 & -2.994 & -9.512 & -11.964 \\
\hline & [2018] & [2018] & [2010] & [2010] \\
\hline & $(0.320)$ & $(0.913)$ & $(<0.01)$ & $(<0.01)$ \\
\hline \multirow{3}{*}{ RDE } & -3.019 & -4.197 & -6.183 & -6.335 \\
\hline & [1998] & [2008] & [1996] & [1996] \\
\hline & $(0.675)$ & $(0.261)$ & $(<0.01)$ & $(<0.01)$ \\
\hline \multirow{3}{*}{ REC } & -5.949 & -7.203 & -3.792 & -4.538 \\
\hline & [2002] & [2002] & [2003] & [2011] \\
\hline & $(<0.01)$ & $(<0.01)$ & $(0.239)$ & $(0.118)$ \\
\hline \multirow{3}{*}{ TOP } & -2.321 & -2.929 & -6.433 & -6.256 \\
\hline & [1990] & [2011] & [2009] & [2009] \\
\hline & $(0.942)$ & $(0.931)$ & $(<0.01)$ & $(<0.01)$ \\
\hline
\end{tabular}

Note: [ ] bracket shows break dates and bracket shows probability value. GHG shows GHG emissions, WA shows women's autonomy, FLFPR shows female labor force participation rate, PAP shows patents application, RDE shows R\&D expenditures, REC shows renewable energy consumption, and TOP shows trade openness.

Table 6 shows the ARDL cointegration estimates. The seven different models evaluate with varying variables of response and exogenous factors. The results show that all the seven stated models possessed the long-run co-integration as Wald F statistics are far more significant than the Narayan upper bound I(1) values at a $1 \%$ significance level. The set of exogenous variables are more than five; thus, it set a fixed lag length order of two for this purpose. The different lag lengths were computed for each model to assessed further diagnostic tests of the error term. Model -I and Model -VII found the best-fitted model as both the models achieved no normality issue, serial correlation, heteroskedasticity, and model stability. In contrast, the remaining models may suffer any one of the problems stated in their models. The study pursued the model-I to evaluate parameter estimates in the short and long-run for policy inferences based on the estimates.

Table 7 shows the ARDL bounds testing estimates and found that in the short-run, women's autonomy has a positive impact on environmental quality as it substantially decreases GHG emissions with open innovation factors. This result is further complementing with the open innovation factors, i.e., patent applications and R\&D expenditures that are interacted with females share in the participation rate of the labor force and women's autonomy, respectively, to decrease GHG emissions. The moderation inverted U-shaped relationship is found in both situations by indicating some threshold values that are latterly discussed in Figure 3. Patent applications and R\&D expenditures deteriorate environmental quality and exacerbate GHG emissions due to unsustainable technology spillovers. However, it is a good sign when open innovation technologies empower women to increase their technical skills and expertise, leading to green development. The role of renewable energy consumption in mitigating GHG emissions is evident that it is crucial to transfuse it through knowledge spillovers in women's autonomy to benefit it for achieving green growth agenda. The moderation results found a U-shaped relationship between renewable energy and women's autonomy in a given period. The results are in line with the 
earlier studies of Terry [69], Ergas and York [70], Jerneck [71], Wang et al. [72], and McGee et al. [73]. These studies mainly provoked in favor of women empowerment that's resulting impact on tackling climate change issues. Terry [69] argued that without empowering women and gender equality, the policies related to mitigating carbon emissions would be unable to be implemented successfully. Thus, carbon mitigation strategies would be designed as gender-specific to cope with adverse environmental externalities that help compliance with international standards and protocols that improve air quality. Ergas and York [70] found that carbon emissions were substantially lower in those countries where women have greater freedom of political autonomy. Women are more likely to care for the environment than men due to their instinct to simultaneously manage the household and corporate affairs. Without including women in the decision-making process, the nation does not fully comply with the international agreements of tackling climate issues. Jerneck [71] concluded that gender equality promotes sustainable development through environmental knowledge and technological spillovers. Wang et al. [72] confined their study's findings in favor of females' share in the labor force, contributing to lower carbon emissions by acquiring education and political autonomy. McGeet et al. [73], in a similar line, concluded that attaining social justice and gender equality interlinked with the environmental quality to support lowering negative environmental externalities globally.

In the long-run, the results show that women's autonomy substantially improves environmental quality and decreases GHG emissions under the premise of increasing R\&D expenditures that lead to its inverted U-shaped relationship between them. The turning point is estimated and is latterly discussed in Figure 1 for reference. The flat relationship is found between patent applications' interaction and females' share in labor force participation rate and GHG emissions. The impact of renewable energy consumption on GHG emissions is positive while using interaction terms with women's autonomy; it exhibits the U-shaped relation with GHG emissions. The greater need to empower women through knowledge and technological spillovers is vital for progressing green growth development agendas. The negative impact of trade openness and GHG emissions indicated the viability of the pollution haven hypothesis in a country. The stringent environmental regulations and carbon pricing would be crucial to limit dirty polluting industries. The results are in line with the subsequent studies, including, Aluko and Okuwa [74], Musango et al. [75], Rola-Rubzen et al. [76], Rosca et al. [22], Brugere et al. [77], and Nhamo and Mukonza [21]. These studies argued that through technological spillovers, women's empowerment would help improve environmental protection. Aluko and Okuwa [74] discussed that innovative and technical solutions empower women to improve their lives while it further equips them with specialized skills that can devise global environmental protection policies. Musango et al. [75] emphasized the need to achieve energy efficiency by promoting gender into the mainstream of policy decisions to progress towards green development. Rola-Rubzen et al. [76] described that agricultural transformation is gender-specific due to deeply rooted socio-cultural barriers that restrict women from accessing agricultural technologies and finance on an equity basis. The provision of equal accessibility of farm technologies to women would help transform the agricultural sector to meet the food challenges. Rosca et al. [22] argued that women social entrepreneurs are confined their strengths to addressing social issues while equally motivated to perform in the decision-making process to promote their economic development. Brugere et al. [77] suggested that absorptive capacity and innovative technologies help transform women's abilities to perform better in agricultural farming. Nhamo and Mukonza [21] found that women's role in sustainable business would likely increase available opportunities that lead to them at higher management positions. Hence, women's engagement in the green business sector is crucial and gives them the empowerment to progress in this field to contribute to their country. 
Table 6. Results of the ARDL co-integration test.

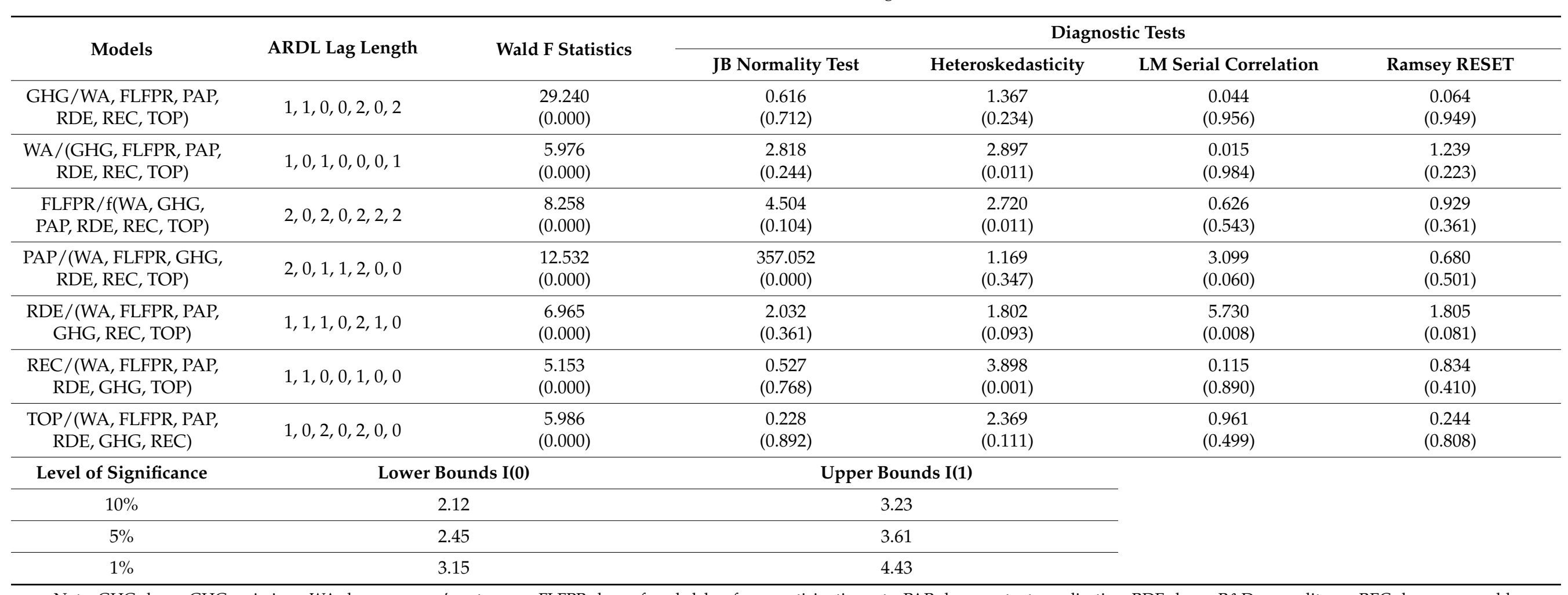

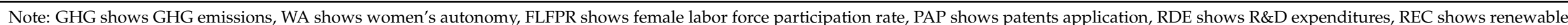
energy consumption, and TOP shows trade openness. 
Table 7. Estimates of ARDL co-integrating and long run form.

\begin{tabular}{|c|c|c|c|c|}
\hline Variables & ARDL-1 & ARDL-2 & ARDL-3 & ARDL-4 \\
\hline \multicolumn{5}{|c|}{ Short-Run Elasticities } \\
\hline$\Delta(\mathrm{WA})_{\mathrm{t}}$ & $-34,915.853 *$ & 2803.761 & $-37,095.401^{*}$ & $-106,212.938 *$ \\
\hline$\Delta(\text { FLFPR })_{\mathrm{t}}$ & $-31,855.830$ & $371,818.173^{* * *}$ & $115,916.400$ * & $386,232.326^{* * *}$ \\
\hline$\Delta(\text { FLFPR })_{t-1}$ & - & - & - & - \\
\hline$\Delta(\mathrm{PAP})_{\mathrm{t}}$ & 0.045 & $0.559^{* * *}$ & $6.246^{* * *}$ & -0.069 \\
\hline$\Delta(\text { FLFPR } \times \text { PAP })_{\mathrm{t}}$ & - & - & $-0.107^{* * *}$ & - \\
\hline$\Delta(\mathrm{RDE})_{\mathrm{t}}$ & $-783,064.803^{* * *}$ & $1,425,171.961$ * & $-199,276.009$ & $-741,426.481$ \\
\hline$\Delta(\mathrm{RDE})_{\mathrm{t}-1}$ & - & $1,444,405^{* *}$ & $-1,494,031.598 *$ & - \\
\hline$\Delta(\mathrm{WA} \times \mathrm{RDE})_{\mathrm{t}}$ & - & $-33,188.237$ & - & - \\
\hline$\Delta(\mathrm{REC})_{\mathrm{t}}$ & $-90,850.166^{*}$ & $-98,005.904 *$ & $-116,630.336^{*}$ & $-309,411.376^{*}$ \\
\hline$\Delta(\mathrm{WA} \times \mathrm{REC})_{\mathrm{t}}$ & - & - & - & $3619.651^{* *}$ \\
\hline$\Delta(\mathrm{TOP})_{\mathrm{t}}$ & $9215.337 * *$ & 6758.338 & $-10,793.499 * * *$ & $8435.074^{* * *}$ \\
\hline$\Delta(\mathrm{TOP})_{\mathrm{t}-1}$ & - & $-11,110.708^{* *}$ & - & $10,321.316^{* *}$ \\
\hline$(\text { CointEq })_{t-1}$ & $-0.096^{* *}$ & $-0.161 *$ & $-0.116^{*}$ & $-0.165 *$ \\
\hline \multicolumn{5}{|c|}{ Long-Run Elasticities } \\
\hline WA & $-912,548.956^{* *}$ & $17,367.135$ & $-710,080.365^{*}$ & $-984,840.214 *$ \\
\hline FLFPR & $-328,595.722$ & $514,111.254$ & $998,807.638 *$ & $-191,529.851$ \\
\hline PAP & 0.507 & $3.463^{* *}$ & 53.826 & -0.422 \\
\hline FLFPR $\times$ PAP & - & - & -0.879 & - \\
\hline RDE & $-1,579,472.739$ & $35,968,085.561 *$ & $5,751,961.866^{* * *}$ & $4,133,012.289$ \\
\hline $\mathrm{WA} \times \mathrm{RDE}$ & - & $-467,246.674 *$ & - & - \\
\hline REC & $-937,127.547^{*}$ & $-607,029.354^{*}$ & $-1,004,959.350 *$ & $-1,871,581.361$ * \\
\hline $\mathrm{WA} \times \mathrm{REC}$ & - & - & - & $21,894.768$ * \\
\hline TOP & $160,201.109 * *$ & $102,762,276$ * & $147481.962^{*}$ & $95,947.406^{*}$ \\
\hline Constant & $110,511,580.3$ & $-21,211,643.103$ & - & $91,157,188.676^{* *}$ \\
\hline \multicolumn{5}{|c|}{ Diagnostic Tests } \\
\hline Wald F Statistics & 29.240 * & 25.694 & $22.392 *$ & $23.360 *$ \\
\hline JB Test & 0.228 & 0.195 & 0.632 & 0.456 \\
\hline $\begin{array}{c}\text { LM Serial } \\
\text { Correlation Test }\end{array}$ & 2.369 & 0.050 & 0.014 & 0.039 \\
\hline Heteroskedasticity Test & 0.961 & 1.070 & 1.314 & 1.081 \\
\hline Ramsey RESET Test & 0.244 & 0.821 & 0.748 & $1.958^{* * *}$ \\
\hline
\end{tabular}

Note: ${ }^{*}, * *$, and ${ }^{* * *}$ shows $1 \%, 5 \%$ and $10 \%$ significance level. GHG shows GHG emissions, WA shows women's autonomy, FLFPR shows female labor force participation rate, PAP shows patents application, RDE shows R\&D expenditures, REC shows renewable energy consumption, and TOP shows trade openness. 


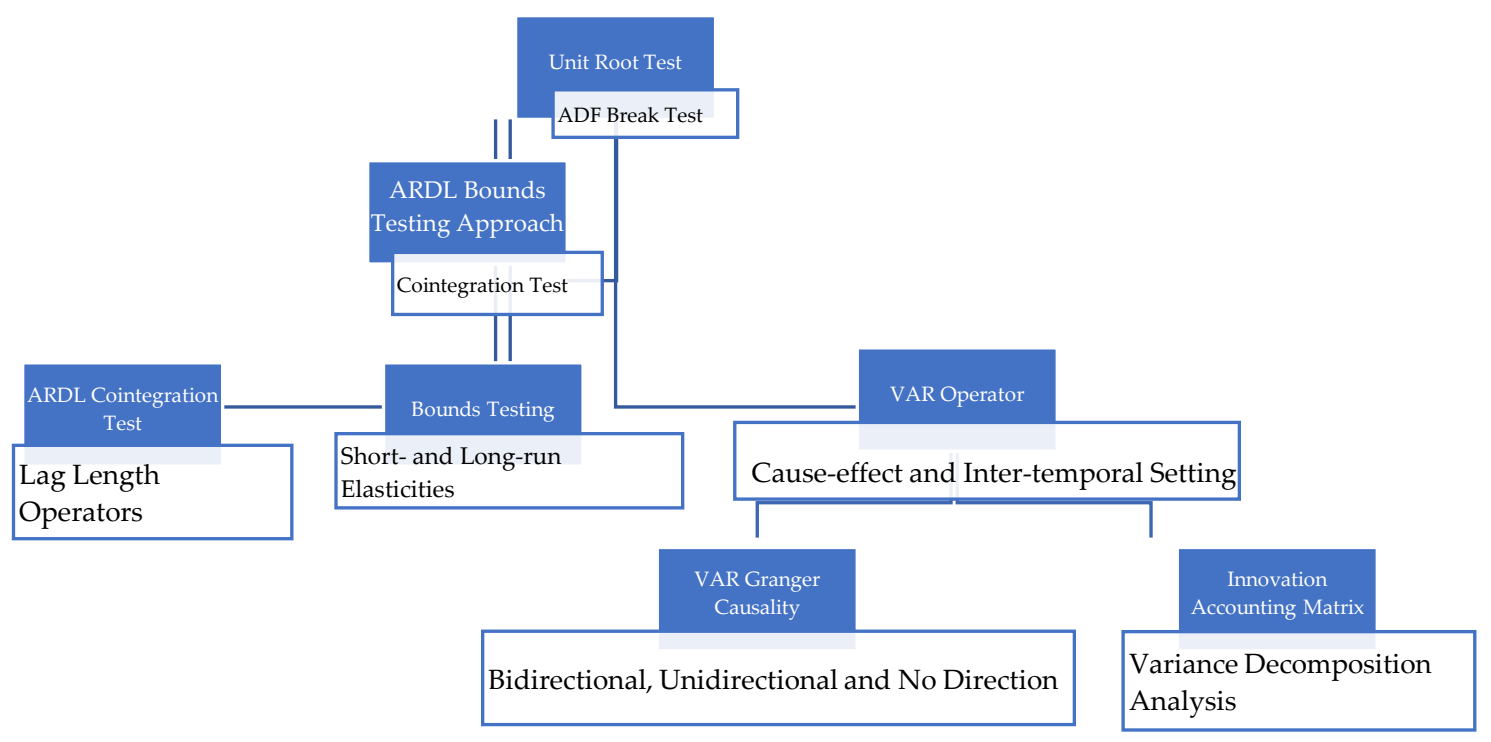

Figure 3. Sequential methodological flow. Source: Author's extraction.

\section{Discussion}

This section discussed the crucial findings from the ARDL estimates. The key result is the estimation of the moderation turning point that helps policymakers devise long-term sustained economic policies to empower women to tackle environmental issues. Figure 4 shows the moderation turning points for ready reference.
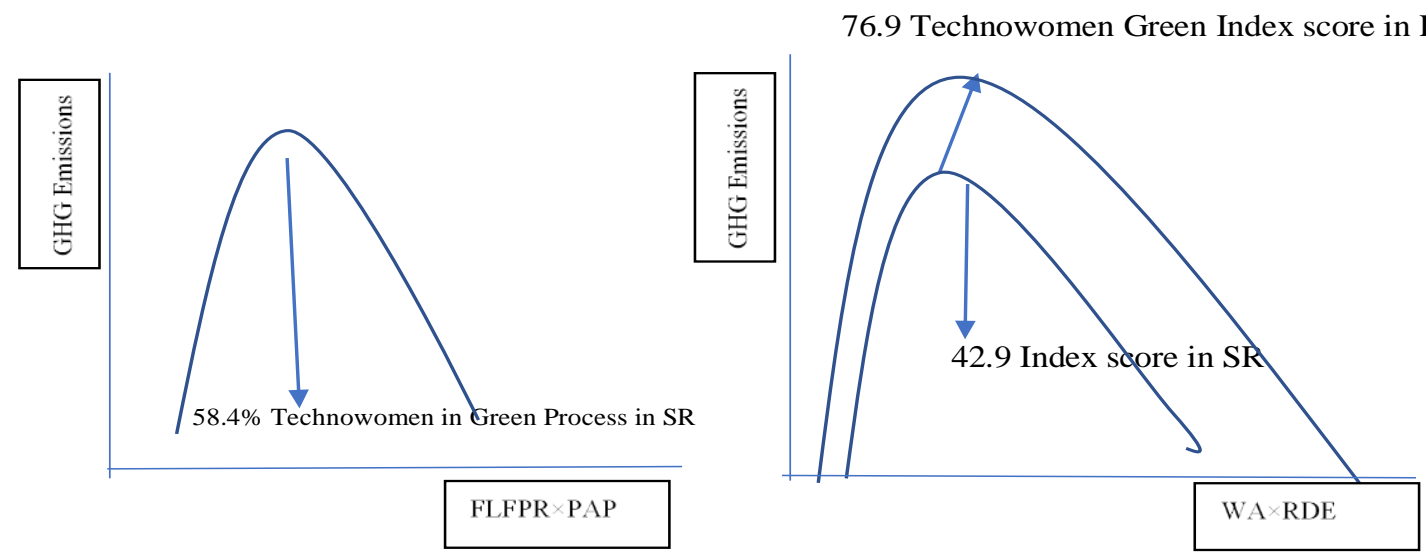

Figure 4. Moderation Turning Points. Source: Author's estimation. Note: SR shows short-run, LR shows long-run, GHG shows GHG emissions, FLFPR shows female labor force participation rate, PAP shows patents applications, WA shows women's autonomy, and RDE shows R\&D expenditures.

The moderation turning point shows that in the short-run, the impact of an interaction term of females' labor force participation rate and patent applications on GHG emissions is a hump-shaped relationship with the turning point of $58.4 \%$ female share in labor force participation. The country achieved this turning point at $58.4 \%$ by increasing more women in the labor force to contribute to economic development. Further, in the short- and longrun, there are a rise and fall in the GHG emissions due to empower women on technical grounds and this increases a large sum of R\&D expenditure on women's development that further enables them to decrease GHG emissions due to their friendly environmental autonomy features. The moderation turning point is a 42.9 index score in the short-run and a 76.9 index score in the long-run. The country has already achieved the short-run index score. Simultaneously, it is a little far lag in achieving the long-run index score, which is crucial for attaining it by empowering more autonomy to the women at political 
and economic participation. Table 8 shows the VAR Granger causality estimates for ready reference.

Table 8. Estimates of VAR Granger causality.

\begin{tabular}{cc}
\hline Bidirectional Causality & Unidirectional Causality \\
\hline $\mathrm{FLFPR} \leftrightarrow \mathrm{WA}$ & $\mathrm{WA} \rightarrow \mathrm{GHG}$ \\
\hline $\mathrm{RDE} \leftrightarrow \mathrm{FLFPR}$ & $\mathrm{PAP} \rightarrow \mathrm{WA}$ \\
\hline $\mathrm{GHG} \leftrightarrow \mathrm{RDE}$ & $\mathrm{REC} \rightarrow \mathrm{WA}$ \\
\hline $\mathrm{FLFPR} \leftrightarrow \mathrm{RDE}$ & $\mathrm{RDE} \rightarrow \mathrm{PAP}$ \\
\hline & $\mathrm{FLFPR} \rightarrow \mathrm{REC}$ \\
\hline & $\mathrm{FLFPR} \rightarrow \mathrm{TOP}$ \\
\hline
\end{tabular}

Note: GHG shows GHG emissions, WA shows women's autonomy, FLFPR shows female labor force participation rate, PAP shows patents application, RDE shows R\&D expenditures, REC shows renewable energy consumption, and TOP shows trade openness.

The results confirmed that females' share in labor force participation causes renewable energy consumption and trade openness, which verifies hypothesis 2 in the study. The result implies that women are more environmentally friendly than their male counterparts; thus, their natural autonomy attracts more green energy than conventional wood stoves in cooking and fossil fuel combustion in corporate and household affairs. Besides its environmentally friendly approach, women-centric traded goods are more likely to increase trade volume, which is vital for progressing long-term development. There is a oneway causal link of patent applications and renewable energy consumption to women's autonomy, while women's freedom causes GHG emissions. Thus, there is a greater need for enabling women with technically equipped to improve the country's environmental quality. The bidirectional causality is found between females' labor force participation rate and women's autonomy and R\&D expenditures, which verifies hypothesis number 1 in the study. Further, there is a two-way causality between R\&D expenditures and female labor force participation rate and between GHG emissions and R\&D expenditures. On the one hand, R\&D expenditures empower women to increase their share in the labor force participation rate, while on the other hand, it is mixed with GHG emissions. Thus, it is crucial to add women to a sustainable development agenda to achieve a country's long-term sustained growth. Table 9 shows the estimates of VDA for the next ten years' time period.

Table 9. Variance decomposition of GHG estimates.

\begin{tabular}{ccccccccc}
\hline Period & S.E. & GHG & WA & FLFPR & PAP & RDE & REC & TOP \\
\hline 2021 & $236,575.4$ & 86.566 & 6.290 & 0.122 & 1.340 & 4.100 & 1.277 & 0.300 \\
2022 & $290,966.7$ & 78.553 & 8.779 & 0.940 & 3.669 & 4.547 & 1.690 & 1.818 \\
2023 & $319,087.3$ & 70.054 & 9.912 & 4.920 & 5.272 & 4.176 & 1.510 & 4.153 \\
2024 & $349,212.1$ & 58.493 & 8.916 & 14.289 & 6.627 & 3.494 & 2.798 & 5.381 \\
2025 & $401,109.7$ & 46.909 & 6.848 & 25.699 & 6.008 & 3.061 & 5.867 & 5.605 \\
2026 & $485,264.6$ & 38.394 & 6.184 & 33.202 & 4.269 & 3.520 & 9.183 & 5.244 \\
2027 & $598,270.5$ & 33.273 & 7.103 & 35.625 & 2.842 & 5.097 & 11.132 & 4.924 \\
2028 & $731,524.4$ & 29.971 & 8.341 & 34.980 & 2.298 & 7.546 & 11.971 & 4.891 \\
2029 & $875,548.7$ & 27.531 & 9.122 & 33.141 & 2.412 & 10.461 & 12.310 & 5.021 \\
\hline
\end{tabular}

Note: GHG shows GHG emissions, WA shows women's autonomy, FLFPR shows female labor force participation rate, PAP shows patents application, RDE shows R\&D expenditures, REC shows renewable energy consumption, and TOP shows trade openness.

The results show that the more significant variance shocks of females' share in labor force participation rate will exert on GHG emissions with a percentage share of $33.141 \%$, followed by renewable energy consumption, i.e., $12.310 \%$; R\&D expenditures, i.e., $10.461 \%$; women's autonomy, i.e., $9.122 \%$; and trade openness, i.e., $5.021 \%$. The least variance 
shocks of patent applications will affect GHG emissions with a share of $2.412 \%$ for the next ten-year period. The results suggested that females' share in labor force participation rate will decrease GHG emissions by increasing R\&D expenditures and renewable energy consumption, empowering women through technology and knowledge spillovers. The open innovation process helps women equip themselves with cleaner production technologies that need a green energy infrastructure to mitigate climate changes to proceed for sustainable development.

\section{Conclusions and Policy Implications}

The United Nations SDG-5 has mainly focused on gender equality, and it primarily favors women's empowerment that severally victimizes many parts of the globe through its larger discriminations in all forms. The study focused on women's autonomy and its impact on China's sustainable development agenda by using a time series data from 1975 to 2019. The results confirmed that women's liberation enabled technological spillovers to engage them in the decision-making process to devise environmentally friendly policies to decrease the cost of carbon emissions. The moderation impact of technical factors on women's autonomy verifies the inverted U-shaped relationship with GHG emissions in a country. The trade liberalization policies supported the country's economic growth, while its deteriorating country's natural environment substantiated the pollution haven hypothesis. The stringent environmental regulations, sustainable technologies, and green energy demand empower women in the decision-making process to formulate environmentally friendly policies to combat climate change. The causality estimates show that the increasing share of females' labor force participation rate moves together with women's autonomy in both directions. Similarly, R\&D expenditures move in the same direction as females' share in labor force participation and GHG emissions. Technology-led women's autonomy and energy led to women's freedom to confirm a country data set. The percentage of female participation in the labor force is the cause of green energy demand, while it leads to trade openness in a country. The inter-temporal relationship suggests that women's empowerment can be enabled with an open innovation system that accesses ownership of control in economic and political decisions to combat climate changes. The following three central policies are suggested in support of a women-centric approach to decrease the cost of carbon emissions in a country.

i. Empowering women through technological spillovers would help build human capital infrastructure that can reduce gender disparity in the socio-economic system and enable them in the decision-making process to achieve the environmental sustainability agenda.

ii. Mainstreaming women into the labor force and financial system enable them to take economic and political decisions to help them reduce exacerbating costs of carbon emissions and devise green policies, including the sustainable use of technologies, achieving energy efficiency, use of renewable energy mixes, and carbon pricing to combat climate change issues.

iii. Promoting gender equality would be a significant contribution to progress across all the United Nations SDGs. Poverty and hunger (SDG-2 and 3) can be eliminated by empowering women in the labor force. Healthy and wealthy well-being (SDG-3) could enable women involved in reproductive healthcare decisions. Ensuring access to quality education (SDG-4) without gender discrimination can be reduced. Clean sanitation and a green energy agenda (SDG-6 and 7) could allow women to with technical expertise and reduce inequalities (SDG-10) through enabling women in the decision-making process. Climate actions (SDG-13) could be more crucial without involving women in economic and environmental decisions.

The sustainable innovation system, green energy consumption, carbon pricing, and environmental regulations are a few policy options that can empower women in the economic and political scenario. Thus, unlocking women's potential in the social, economic, and environmental process leads to clean and green development worldwide. 
Author Contributions: Conceptualization, S.M. and S.L.; methodology, S.M.; software, S.L.; validation, K.Z., S.M. and S.L.; formal analysis, S.M., K.Z., M.J., A.A.N., S., and H.J.; investigation, S.M., S.L., M.J., A.A.N., S., and H.J.; resources, S.M., S.L., A.A.N., S.E.A., M.M.Q.A. and K.Z.; data curation, S.M., M.J., S., H.J., and K.Z.; writing—original draft preparation, S.M.; writing-review and editing, S.M., S.L., M.J., A.A.N., S.E.A., M.M.Q.A., S., and H.J.; visualization, S.M., M.J., S.E.A., S., H.J., and K.Z.; supervision, S.L. All authors have read and agreed to the published version of the manuscript.

Funding: Researchers Supporting Project number (RSP-2020/167), King Saud University, Riyadh, Saudi Arabia.

Institutional Review Board Statement: Not applicable.

Informed Consent Statement: Not applicable.

Data Availability Statement: The data is freely available at World Development Indicators published by World Bank (2020) at https:/ / databank.worldbank.org/source/world-development-indicators.

Acknowledgments: Researchers Supporting Project number (RSP-2020/167), King Saud University, Riyadh, Saudi Arabia.

Conflicts of Interest: The authors declare no conflict of interest.

\section{References}

1. United Nations. \#Envision2030 Goal 5: Gender Equality. Goal 5: Achieve Gender Equality and Empower All Women and Girls. 2015. Available online: http://www.un.org/development/desa/disabilities/envision2030-goal5.html (accessed on 4 December 2020).

2. Jia, Y. Report on Women's Development in China in 2016. In Chinese Research Perspectives on Society; Brill: Leiden, The Netherlands, 2019; Volume 6, pp. 385-404.

3. Sebire, J. Why Gender Equality in Policing is Important for Achieving United Nations Sustainable Development Goals 5 and 16. Int. J. Crime Justice Soc. Democr. 2020, 9, 80-85. [CrossRef]

4. Yang, J. Women in China moving forward: Progress, challenges and reflections. Soc. Incl. 2020, 8, 23-35. [CrossRef]

5. Ryan, J. Education in China: Philosophy, Politics and Culture; John Wiley \& Sons: Hoboken, NJ, USA, 2019.

6. World Bank. World Development Indicators; World Bank: Washington, DC, USA, 2020.

7. Awan, U.; Nauman, S.; Sroufe, R. Exploring the effect of buyer engagement on green product innovation: Empirical evidence from manufacturers. Bus. Strategy Environ. 2020. [CrossRef]

8. Cheng, Y.; Awan, U.; Ahmad, S.; Tan, Z. How do technological innovation and fiscal decentralization affect the environment? A story of the fourth industrial revolution and sustainable growth. Technol. Forecast Soc. Chang. 2020, 162, 120398. [CrossRef]

9. Mehra, R. Women, empowerment, and economic development. Ann. Am. Acad. Political Soc. Sci. 1997, 554, 136-149. [CrossRef]

10. Sharma, P.R. Micro-finance and women empowerment. J. Nepal. Bus. Stud. 2007, 4, 16-27. [CrossRef]

11. Shirazi, F. Information and communication technology and women empowerment in Iran. Telemat. Inform. 2012, 29, 45-55. [CrossRef]

12. Duflo, E. Women empowerment and economic development. J. Econ. Lit. 2012, 50, 1051-1079. [CrossRef]

13. Bushra, A.; Wajiha, N. Assessing the socio-economic determinants of women empowerment in Pakistan. Procedia Soc. Behav. Sci. 2015, 177, 3-8. [CrossRef]

14. Tandon, T. Women empowerment: Perspectives and views. Int. J. Indian Psychol. 2016, 3, 6-12.

15. Karwati, L.; Ansori, A.; Mulyono, D. Women Empowerment to Build Entrepreneurship. J. Nonform. Educ. 2018, 4, 169-176. [CrossRef]

16. Nassani, A.A.; Aldakhil, A.M.; Abro, M.M.Q.; Islam, T.; Zaman, K. The impact of tourism and finance on women empowerment. J. Policy Model. 2019, 41, 234-254. [CrossRef]

17. Khayyal, A.O.A.; Alshurideh, M.; Kurdi, B.A.; Salloum, S.A. Women empowerment in UAE: A systematic review. In International Conference on Advanced Intelligent Systems and Informatics; Springer: Cham, Switzerland, 2020; pp. 742-755.

18. Harper, S.; Adshade, M.; Lam, V.W.; Pauly, D.; Sumaila, U.R. Valuing invisible catches: Estimating the global contribution by women to small-scale marine capture fisheries production. PLoS ONE 2020, 15, e0228912. [CrossRef] [PubMed]

19. Dhal, S.; Srivastava, N.; Lane, L. Does ICS Technology Contribute to Gender Empowerment: Empirical Evidence from Odisha. Political Econ. J. India 2019, 28, 50.

20. Sorensen, C.; Saunik, S.; Sehgal, M.; Tewary, A.; Govindan, M.; Lemery, J.; Balbus, J. Climate Change and Women's Health: Impacts and Opportunities in India. GeoHealth 2018, 2, 283-297. [CrossRef] [PubMed]

21. Nhamo, G.; Mukonza, C. Opportunities for women in the green economy and environmental sectors. Sustain. Dev. 2020. [CrossRef]

22. Rosca, E.; Agarwal, N.; Brem, A. Women entrepreneurs as agents of change: A comparative analysis of social entrepreneurship processes in emerging markets. Technol. Forecast. Soc. Chang. 2020, 157, 120067. [CrossRef] 
23. Soni, R.; Mathai, W.; Davis, L.; Njenga, M. Women in Energy: Perspectives on Engaging Women across the Energy Value Chain: The Case of wPOWER. In Recovering Bioenergy in Sub-Saharan Africa: Gender Dimensions, Lessons and Challenges; 2018; Available online: http:/ / www.iwmi.cgiar.org/Publications/wle/rrr/special_issue-chapter-8.pdf (accessed on 2 February 2021).

24. Pirani, N.; Ricker, B.A.; Kraak, M.J. Feminist cartography and the United Nations Sustainable Development Goal on gender equality: Emotional responses to three thematic maps. Can. Geog. Geogr. Can. 2020, 64, 184-198. [CrossRef]

25. Agarwal, B. Gender equality, food security and the sustainable development goals. Curr. Opin. Environ. Sustain. 2018, 34, 26-32. [CrossRef]

26. Pathania, S.K. Sustainable Development Goal: Gender Equality for Women's Empowerment and Human Rights. Int. J. Res. Granthaalayah 2017, 5, 72-82. [CrossRef]

27. Patel, L. Gender: Toward gender equality and poverty reduction. In Handbook of Social Policy and Development; Edward Elgar Publishing: Cheltenham, UK, 2019.

28. Miotto, G.; Vilajoana-Alejandre, S. Gender equality: A tool for legitimacy in the fast fashion industry. Harv. Deusto Bus. Res. 2019, 8, 134-147. [CrossRef]

29. Rehman, H.; Moazzam, D.A.; Ansari, N. Role of microfinance institutions in women empowerment: A case study of Akhuwat, Pakistan. South. Asian Stud. 2015, 30, 107-125.

30. Yaya, S.; Uthman, O.A.; Ekholuenetale, M.; Bishwajit, G. Women empowerment as an enabling factor of contraceptive use in sub-Saharan Africa: A multilevel analysis of cross-sectional surveys of 32 countries. Reprod. Health 2018, 15, 214. [CrossRef] [PubMed]

31. Yasmin, N.; Grundmann, P. Home-cooked energy transitions: Women empowerment and biogas-based cooking technology in Pakistan. Energe Policy 2020, 137, 111074. [CrossRef]

32. Oyawole, F.P.; Shittu, A.; Kehinde, M.; Ogunnaike, G.; Akinjobi, L.T. Women empowerment and adoption of climate-smart agricultural practices in Nigeria. Afr. J. Econ. Manag. Stud. 2020. [CrossRef]

33. Mbaye, L.M. Weather Shocks and Women Empowerment. In Women and Sustainable Human Development; Palgrave Macmillan: Cham, Switzerland, 2020; pp. 37-49.

34. Goel, S.; Gupta, P. Role of Smartphone in women empowerment. Int. J. Knowl. Based Organ. 2019, 9, 1-11. [CrossRef]

35. Besnier, E. Women political empowerment and child health: An empirical analysis, 1990-2016. Eur. J. Public Health 2019, 29 (Suppl. 4), ckz186-096. [CrossRef]

36. Van der Waldt, G.; Fourie, D.J.; Van Dijk, G.; Chitiga-Mabugu, M.; Jordaan, J. A Competency Framework for Women Empowerment: The Case of the Local Government Sector in South Africa. UPSpace Institutional Repository 2019. Available online: https: / / repository.up.ac.za/handle/2263/75872 (accessed on 4 December 2020).

37. Zhou, H.Z.; Johnston, K. A Road to Empowerment: Social Media Usage by Women Entrepreneurs in China. In European Conference on Innovation and Entrepreneurship; Academic Conferences International Limited: Reading, UK, 2020; pp. 889-892.

38. Zhou, Y.; Sun, X. Toward gender sensitivity: Women and climate change policies in China. Int. Fem. J. Politics 2020, 22, 127-149. [CrossRef]

39. Saleem, H.; Jiandong, W.; Aldakhil, A.M.; Nassani, A.A.; Abro, M.M.Q.; Zaman, K.; Khan, A.; Bin Hassan, Z.; Rameli, M.R.M. Socio-economic and environmental factors influenced the United Nations healthcare sustainable agenda: Evidence from a panel of selected Asian and African countries. Environ. Sci. Pollut. Res. 2019, 26, 14435-14460. [CrossRef]

40. Salahodjaev, R.; Jarilkapova, D. Women in parliament and deforestation: Cross-country evidence. J. Nat. Conserv. 2020, 55, 125830. [CrossRef]

41. DiRienzo, C.E.; Das, J. Women in government, environment, and corruption. Environ. Dev. 2019, 30, 103-113. [CrossRef]

42. Hillman, R. Are Women Leaders of Nature?-A Quantitative Study on the Effect of Women's Political Representation on Environmental Politics in European Countries. 2020. Available online: https://gupea.ub.gu.se/bitstream/2077/63686/1/gupea_2077_6 3686_1.pdf (accessed on 16 January 2021).

43. Lv, Z.; Deng, C. Does women's political empowerment matter for improving the environment? A heterogeneous dynamic panel analysis. Sustain. Dev. 2019, 27, 603-612. [CrossRef]

44. Asteria, D.; Budidarmono, H.H.; Ni'Mah, N.L. Gender sensitive education in watershed management to support environmental friendly city. In IOP Conference Series: Earth and Environmental Science; IOP Publishing Ltd.: Bristol, UK, 2018; Volume 126, p. 012146.

45. Lekshmi, B.; Sharma, S.; Sutar, R.S.; Parikh, Y.J.; Ranade, D.R.; Asolekar, S.R. Circular Economy Approach to Women Empowerment Through Reusing Treated Rural Wastewater Using Constructed Wetlands. In Waste Management as Economic Industry Towards Circular Economy; Springer: Singapore, 2020; pp. 1-10.

46. Bhallamudi, I.; Lingam, L. Swaying between saving the environment and mitigating women's domestic drudgery: India's efforts at addressing clean cooking fuels. Gend. Technol. Dev. 2019, 23, 36-54. [CrossRef]

47. Adendorff, C.M.; Keown, H.; Amansure, R. The development of a socio-economic model to promote women's empowerment initiatives in the renewable energy sector of South Africa. J. Energy South. Afr. 2020, 31, 34-47. [CrossRef]

48. Dutta, S. Promoting Women's Entrepreneurship in Distribution of Energy Technologies: Lessons from ENERGIA's WEE Programme. IDS Bull. 2020, 51, 71-90. [CrossRef]

49. Ahmad, M.; Muslija, A.; Satrovic, E. Does economic prosperity lead to environmental sustainability in developing economies? Environmental Kuznets curve theory. Environ. Sci. Pollut. Res. 2021. [CrossRef] 
50. Grabara, J.; Tleppayev, A.; Dabylova, M.; Mihardjo, L.W.; Dacko-Pikiewicz, Z. Empirical Research on the Relationship Amongst Renewable Energy Consumption, Economic Growth and Foreign Direct Investment in Kazakhstan and Uzbekistan. Energies 2021, 14, 332. [CrossRef]

51. Khan, M.A.; Ozturk, I. Examining foreign direct investment and environmental pollution linkage in Asia. Environ. Sci. Pollut. Res. 2020, 27, 7244-7255. [CrossRef]

52. Rathee, R.; Rajain, P. Economic development: Role of women entrepreneurs. South. Asian J. Mark. Manag. Res. 2017, 7, 14-20.

53. Islam, M.R.; Ingham, V.; Hicks, J.; Manock, I. The changing role of women in resilience, recovery and economic development at the intersection of recurrent disaster: A case study from Sirajgang, Bangladesh. J. Asian Afr. Stud. 2017, 52, 50-67. [CrossRef]

54. Cooke, F.L.; Xiao, M. Women entrepreneurship in China: Where are we now and where are we heading. Hum. Resour. Dev. Manag. 2020. [CrossRef]

55. Freeman, M.A.; Rudolf, B.; Chinkin, C.; Kroworsch, S.; Sherrier, A. (Eds.) The UN Convention on the Elimination of All Forms of Discrimination against Women: A Commentary; Oxford University Press: Oxford, UK, 2012.

56. De Laet, D.L. Lost in legation: The gap between rhetoric and reality in international human rights law governing women's rights. Glob. Discourse 2018, 8, 387-404. [CrossRef]

57. Fitz-Gibbon, K.; Walklate, S. Eliminating all forms of violence against all women and girls: Some criminological reflections on the challenges of measuring success and gauging progress. In The Emerald Handbook of Crime, Justice and Sustainable Development; Emerald Publishing Limited: Bingley, UK, 2020.

58. Budhwar, P.S.; Saini, D.S.; Bhatnagar, J. Women in management in the new economic environment: The case of India. Asia Pac. Bus. Rev. 2005, 11, 179-193. [CrossRef]

59. Hallward-Driemeier, M.; Hasan, T. Empowering Women: Legal Rights and Economic Opportunities in Africa; The World Bank: Washington, DC, USA, 2012.

60. Gwal, R. Working women: Career breaks and re-entry in a fast-changing business environment. Metamorphosis 2016, 15, 1-9. [CrossRef]

61. Noor, S.; Isa, F.M. Contributing factors of women entrepreneurs' business growth and failure in Pakistan. Int. J. Bus. Glob. 2020, 25, 503-518. [CrossRef]

62. Crittenden, C. Ecofeminism meets business: A comparison of ecofeminist, corporate, and free market ideologies. J. Bus. Ethics 2000, 24, 51-63. [CrossRef]

63. Mellor, M. Ecofeminist political economy. Int. J. Green Econ. 2006, 1, 139-150. [CrossRef]

64. Bauhardt, C. Solutions to the crisis? The Green New Deal, Degrowth, and the Solidarity Economy: Alternatives to the capitalist growth economy from an ecofeminist economics perspective. Ecol. Econ. 2014, 102, 60-68. [CrossRef]

65. Phillips, M.E. Reconnecting with nature: An ecofeminist view of environmental management. Geogr. Res. 2020, 58, 154-166. [CrossRef]

66. Pesaran, H.M.; Shin, Y.; Smith, R.J. Bounds Testing Approaches to the Analysis of Level Relationships. J. Appl. Econom. 2001, 16, 289-326. [CrossRef]

67. Glass, C.; Cook, A.; Ingersoll, A.R. Do women leaders promote sustainability? Analyzing the effect of corporate governance composition on environmental performance. Bus. Strategy Environ. 2016, 25, 495-511. [CrossRef]

68. Subiza-Pérez, M.; Santa-Marina, L.; Irizar, A.; Gallastegi, M.; Anabitarte, A.; Urbieta, N.; Babarro, I.; Molinuevo, A.; Vozmediano, L.; Ibarluzea, J. Who feels a greater environmental risk? Women, younger adults and pro-environmentally friendly people express higher concerns about a set of environmental exposures. Environ. Res. 2020, 181, 108918. [CrossRef] [PubMed]

69. Terry, G. No climate justice without gender justice: An overview of the issues. Gend. Dev. 2009, 17, 5-18. [CrossRef]

70. Ergas, C.; York, R. Women's status and carbon dioxide emissions: A quantitative cross-national analysis. Soc. Sci. Res. 2012, 41, 965-976. [CrossRef] [PubMed]

71. Jerneck, A. What about gender in climate change? Twelve feminist lessons from development. Sustainability 2018, $10,627$. [CrossRef]

72. Wang, S.; Li, Z.; Zhang, H. Does female labor share reduce embodied carbon in trade? Environ. Sci. Pollut. Res. 2020. [CrossRef]

73. McGee, J.A.; Greiner, P.T.; Christensen, M.; Ergas, C.; Clement, M.T. Gender inequality, reproductive justice, and decoupling economic growth and emissions: A panel analysis of the moderating association of gender equality on the relationship between economic growth and CO2 emissions. Environ. Sociol. 2020, 6, 254-267. [CrossRef]

74. Aluko, Y.A.; Okuwa, O.B. Innovative solutions and women empowerment: Implications for sustainable development goals in Nigeria. Afr. J. Sci. Technol. Innov. Dev. 2018, 10, 441-449. [CrossRef]

75. Musango, J.K.; Smit, S.; Ceschin, F.; Ambole, A.; Batinge, B.; Anditi, C.; Petrulaityte, A.; Mukama, M. Mainstreaming gender to achieve security of energy services in poor urban environments. Energy Res. Soc. Sci. 2020, 70, 101715. [CrossRef]

76. Rola-Rubzen, M.F.; Paris, T.; Hawkins, J.; Sapkota, B. Improving Gender Participation in Agricultural Technology Adoption in Asia: From Rhetoric to Practical Action. Appl. Econ. Perspect. Policy 2020, 42, 113-125. [CrossRef]

77. Brugere, C.; Msuya, F.E.; Jiddawi, N.; Nyonje, B.; Maly, R. Can innovation empower? Reflections on introducing tubular nets to women seaweed farmers in Zanzibar. Gend. Technol. Dev. 2020, 24, 89-109. [CrossRef] 